\title{
"STRANGE FASCINATION": WALT WHITMAN, IMPERIALISM, AND THE SOUTH
}

\author{
WENDY KURANT
}

Walt Whitman, the American bard, had a peculiar relationship with the South-both claiming it as his own and regarding it with repugnance. As Deborah Kolb and Andrew Hudgins have shown, in several prose pieces and in conversation with Horace Traubel, Whitman exaggerated the length of time he had spent in the South. Kolb estimates that he "only spent a few months in the South, including his three months' sojourn in New Orleans," yet Whitman claimed in Memorandum During the War that he spent "more than a year's residency" in Virginia alone. ${ }^{1}$ He used his fictitious residency to authorize his opinions about the South, such as when he assured Traubel, "I have seen a good deal of the Southern people-know them well, love them well, would not misjudge them." Though critics have explained the exaggeration as an expression of his desire to unite the country or as a cover for his antipathy toward the South, Edward Said's classic work Orientalism sheds light on another possible motivation. ${ }^{3}$ Claims of extensive knowledge, untainted by direct experience, authorized imperial powers' control of conquered land, because it established them as "a race that knows [the colonized] and what is good for them better than they could possibly know themselves." 4 Whitman's claim to extensive experience and knowledge and his paternalistic assurance that he could not be in error are examples of the colonial discourse that colors his representations of the South. Throughout these depictions, Whitman reveals a compulsive need to control the South.

Whitman was not a stranger to imperialist rhetoric. Critics Walter Grünzweig, David Simpson, M. Jimmie Killingsworth, and George Handley have identified this discourse in Whitman's pre-Leaves of Grass editorials about the Mexican-American War and in the poetry of the 1855, 1856, and 1860 editions of Leaves of Grass; they have also discussed its extensive presence in later works such as "Song of the Redwood-Tree" and "Passage to India." In addition, these critics have identified a number of possible influences on Whitman's embrace of imperialism. Simpson notes that transcendental philosophy itself "makes such [imperialist] gestures both feasible and explicable" (184). Handley points to Adamic longing expressed through Hegelian dialectic: 
The figure of Adam appeals to a desire for innocence in approaching and naming the world so as to ensure a New World originality and authenticity. Such yearning for a complete break from the Old World has paradoxically fostered a Hegelian belief in the inevitable and utterly reliable directive of Western history and a paradoxical lack of interest in social and environmental particulars. (107)

Whitman's use of colonial discourse in his depictions of Southerners has much in common with his deployment of that discourse toward a more likely target, Native Americans. In both cases, he overlooks the original inhabitants in favor of a focus on the resources they formerly controlled.

Said observes that "the main battle in imperialism is over land ... who owned the land, who had the right to settle and work on it, who kept it going, who won it back, and who now plans its future," and the reward for winning this battle is control of commodities. ${ }^{6}$ The costs of capturing and controlling a colony are expected to be repaid by the profits from the resources the new territory contains, and it is likely that the new territory was sought in the first place because of the imperial power's need for resources. Thus, the imperial gaze turns the captured territory into a commodity and establishes sole ownership of the profits by erasing the competing claims of the prior inhabitants. This commodifying eye is evident in Whitman's "Song of the Redwood-Tree," first published in 1873. In a landscape seemingly unpopulated by any aboriginal inhabitants, the song is the "voice of the mighty dying tree" whose death is initiated by the actions of "the choppers ... / The quick-ear'd teamsters and chain and jack-screw men." As Killingsworth and Diane Kirk have observed, the poem is "notably lacking in description of the visible features of the trees," and Whitman's lack of personal experience with the subject is apparent (69). As the dying redwood graciously bids man to "Here build your homes for good" (the likely destination for its wood), likewise all the resources of the west exist only to be available for their conquerors: "the unoccupied surface ripening, the rich ores forming beneath; / At last the New arriving, assuming, taking possession, / A swarming and busy race settling and organizing everywhere" $(P P, 354)$. This consumption is their apotheosis, for they are "the means, the implements, the standingground" of a society that is "more than your mountain peaks or stalwart trees imperial" (PP, 354). As Killingsworth notes, by presenting "nature as a boundless resource base for human expansion, the poem can only offend the sensibilities of modern environmentalists and proponents of environmental justice" (Earth, 64).

Similarly, Whitman's representations of the South, both antebellum and during wartime, construct it as a fecund and depopulated geography, rich in all things except people. First published in 1860 as "Longings for Home," the poem that became "O Magnet-South" in the 1881 edition of Leaves of Grass features a Southern persona expressing his desire 
for his native region. Described by Kolb as "just a conglomeration of landscape features, plants, and animals," the details of the poem, similar to "Song of the Redwood-Tree," were derived not from personal experience but from consultation with a geography textbook. ${ }^{8}$ Consistent with the imperialist gaze, the bulk of this conglomeration relates to profitable products and routes to market. The speaker reviews rivers, lakes, and coastlines. He lists trees that produce lumber and food: "the live-oak ... the yellow-pine, the scented bay-tree, the lemon and orange, the cypress, the graceful palmetto" $(P P, 584)$. In the final third of the poem, he tallies crops such as cotton, rice, sugar, hemp, and corn. While both "Redwood-Tree" and "Magnet-South" prioritize consumable goods and obscure the prior occupants of the areas, "Redwood-Tree" certainly gives more attention to the glorious ends served by these consumable goods. However, a description in Whitman's notebook a few years after the publication of "Magnet-South" demonstrates that he also envisioned the South's products in the service of a greater good.

Whitman sketched Culpepper,Virginia, in his notebook in February of 1864. Omitting any mention of human activity, Whitman rhapsodizes about the economic potential of the state, though currently "dilapidated, fenceless, and trodden with war":

What capacity for products, improvements, human life, nourishment and expansion. Everywhere that I have been in the Old Dominion, (the subtle mockery of that title now!) such thoughts have fill'd me. The soil is yet far above the average of any of the northern states. And how full of breadth the scenery, everywhere distant mountains, everywhere convenient rivers. Even yet prodigal in forest woods, and surely eligible for all the fruits, orchards, and flowers. The skies and atmosphere most luscious. $(P P, 766)$

Brief moments of aesthetic pleasure arise in the description, though even they are consumable, "luscious." The main interest is in how the land could be made to produce. The beneficiary of this production, the imperial power, lurks in the parenthetical comment about Old Dominion; conquered Virginia has lost its dominion, and the North has gained it. Furthermore, Whitman credits the North for that rich environment, perhaps further authorizing its ownership of Virginia's productions. Continuing his description of the "luscious" atmosphere, Whitman asserts: "Then a rich and elastic quality, by night and by day. The sun rejoices in his strength, dazzling and burning, and yet, to me, never unpleasantly weakening. It is not the panting tropical heat, but invigorates. The north tempers it" $(P P, 766)$. The South, unmitigated by the North, causes atavistic qualities - weakened by it, one descends into panting, bestial behavior. In addition to implying Northern ownership of Southern resources, this comment suggests anxiety about the effect of unmitigated "southernness" on a person. Whitman's early represen- 
tations of the South, though they focus mainly on its commodities, also reveal a latent fear of the contagion of southern primitivism. It is on this point that we see a significant distinction between Whitman's treatment of Native Americans and Southerners.

Commodities are relatively easy to control; previous claimants to those commodities are less so. One technique of narrative erasure of the colonial subjects' rights is to figure them as inferior to the colonizer-as "irrational, depraved (fallen), childlike, 'different"” to the colonizer's "rational, virtuous, mature, 'normal" - and therefore in need of the guardianship of the colonizer (Culture, 40). Anne McClintock shows that similar techniques were used for internal colonialism; the language of degeneration and deviance "was evoked to police the 'degenerate' classes" who were "figured as racial deviants, atavistic throwbacks to a primitive moment in human prehistory, surviving ominously in the heart of the modern, imperial metropolis." Like Said's colonizer, Whitman assumes the objective stance of "the listener or the observer of life who is able to sit and look out on life even as he is consumed by its very turmoil." ${ }^{10}$ Yet this narrative position is not truly objective. Killingsworth finds in "Starting from Paumanok" "the imposition of local experience and values on far-ranging peoples and landscapes" (Earth, 88), and Grünzweig shows in "Passage to India" that the "map incognita, blanks ... filled" is clearly a western map reflecting western economic interests (158). Whitman denies the difference of others by erasing their living presence or by engulfing it within his own, confident that he is justified by natural superiority. Discussing Whitman's famous catalogs, Simpson observes that "the ethical questions that might have been raised by such uninhibited self-projection on the part of a dominant culture or individual ... are completely passed over by Whitman. Different voices are lost in or drowned out by the voice, awkward plurality is subsumed in singleness" (184). This technique too affects an erasure, if not of the people themselves then certainly of whatever social tensions their presence evokes. As Simpson observes, even "the complex questions of black-white relations in the decade or so before the Civil War is once again reduced to a celebrative parallelism in which all potential conflicts are subsumed" (186). Whitman clearly deploys these techniques of racial superiority and erasure against Native Americans.

As many critics have described, Whitman presents his erasure of native peoples as a consequence of evolutionary progressivism. In "Proto-Leaf," the advent of "[a] new race, dominating previous ones, and grander far" mirrors the shifting "Elements, breeds, adjustments, turbulent, quick, and audacious" that create a "world primal again-Vistas of glory, incessant and branching" ( $L G$ 1860, 20). ${ }^{11}$ "Redwood-Tree," through its "all too easy substitution of redwood for red people" (Earth, 71 ), has the displaced people announcing their own abdication in favor 
of a "superber race" and its "new culminating man" (PP, 352). Whitman figures their obsolescence through the use of ephemeral imagery. Native Americans in "Proto-Leaf" leave only "natural breaths, sounds of rain and winds, calls as of birds and animals, in the woods, syllabled to us for names" that "melt ... [and] depart, charging the water and the land with names" ( $L G 1860,20)$. The land and water become the property of the conquerors, as those brief sounds cannot inconvenience the "culminating race." "Redwood-Tree" similarly transmutes Native Americans into ephemera. They are a "chorus of dryads, fading, departing, or hamadryads departing, / A murmuring, fateful, giant voice" $(P P, 351)$. However, the ephemeron is not really departing; it will be consumed. The redwood asserts:

... in them ourselves ye forest kings!

In them these skies and airs, these mountain peaks, Shasta, Nevadas, These huge precipitous cliffs, this amplitude, these valleys, far Yosemite, To be in them absorb'd, assimilated. (PP, 352)

These two poems show us Whitman's poetics of inferiority: figures of ephemera and erasure through absorption. Whitman deployed the discourse of racial inferiority against both Native Americans and Southerners. However, while he maintained an objective tone and blithe ability to dismiss Native Americans by simply dissolving them, his discourse directed at Southerners betrays a more intense antipathy along with a struggle - often unsuccessful - to subdue these recalcitrant subjects within a drama for control as much psychological as ideological.

Whitman thought of Southerners as an inferior race. In one description of regional traits, first published in the December 1867 issue of Galaxy Magazine and later reprinted in Democratic Vistas (1871), Whitman asserted that the country gets "from the north, intellect, the sun of things, also the idea of unswayable justice, anchor amid the last, the wildest tempests," and "from the south the living soul, the animus of good and bad, haughtily admitting no demonstration but its own" $(P P, 976)$. While the tone is positive, the pairing puts the South in the role of the irrational, emotionally impulsive colonial subject that must be controlled, "anchored," by imperialist rationality. Later in life, he became less tactful in expression. In a March 1889 conversation with Horace Traubel that starts with Southern wartime prisons and guerrilla warfare but then expands to implicate all Southerners, Whitman asserts, "[Southerners] are behind the North, anyone can see it - behind it at least a generation. They will evolve-but will they ever catch up?" Though he recovers himself and tries to note Southerners' positive qualities, the conversation returns to Southern atavism within one sentence: "but you have no idea, Horace, how really fiendish the disposition of the South 
towards a foe is likely to be: it's hard lines there to be anybody's enemy" ( $W W W C, 4: 331-332$ ). In response to Traubel's question of whether "all Southern people were not prone to desperate anger,"Whitman asserts:

Yes, that is true: I can see it: how it should be in Europe-in Asia: but this is not the same thing - not at all: our Southern people would go to a length of animosity not even manifested by the animals. It was said long ago by naturalists, believed by them, that some of the animals, smelling a body, finding it dead, would pass away, leaving it untouched. Some naturalists believe this yet: think, then, of the prisons South-the guerillas. ( $W W W C, 4: 331-332$ )

In these passages we see Whitman's descriptions of Southerners at their most atavistic; even animals are more civilized in their treatment of prey. Though Traubel tells us that Whitman made these comments with "great feeling" but "no bitterness" ( $W W W C, 4: 332$ ), this is not the tone of gentle regret at the necessary fading of another race, as we see in his depictions of Native Americans; here, it is a visceral revulsion. Correspondingly, Whitman struggles to control these colonial subjects with a range of narrative strategies departing from those discussed previously and is never able to absorb them as he does Native Americans.

As mentioned previously, the southland of "O Magnet-South" is curiously devoid of Southerners; however, the one exception situates Southerners within a predatory drama. In the swamp vignette, one of the longest in the poem's rapid fire catalog of southern places as well as the source of a "strange fascination" for the narrator, Whitman describes the following scene:

The piney odor and the gloom, the awful natural stillness, (here in these dense swamps the freebooter carries his gun, and the fugitive has his conceal'd hut;)

$\mathrm{O}$ the strange fascination of these half-known half-impassible swamps, infested by reptiles, resounding with the bellow of the alligator, the sad noises of the night-owl and the wild-cat, and the whirr of the rattlesnake....(PP, 584)

The freebooter (the term itself has piratical overtones) hunts the fugitive slave and is akin to the other fearsome animal predators that infest the swamp. Against the savagery of Southerners Whitman deploys techniques of textual control. The predatory drama in "O Magnet-South," situated in one of the few non-productive environments in the poem, is first bracketed by evocations of the crops that provide the unacknowledged pre-condition for this event: the passage is preceded by a recitation of the crops of cotton, rice, sugar, and hemp and is followed by a description of a cornfield. In addition, the antagonists are encased in parentheses, as if to insulate the celebration of the southern landscape by making them a tangential observation rather than one of the central distinctions of the South. Through these methods, Whitman makes this 
atavistic drama as half-concealed, half-knowable, and half-impassable as the environment in which he places them. However, they have not been dispersed and absorbed; they are confined, yet they are living, in human form, and forever in the present.

Whitman's Civil War book of poetry, Drum-Taps, repeats Whitman's motif of the Southern irrationality controlled by Northern influences, such as in two poems from the first phase of the cycle, "Eighteen SixtyOne" [originally "1861"] and "Virginia-The West." In "Eighteen SixtyOne," Whitman figures the year of the war's commencement as a Union soldier- "a strong man, erect, clothed in blue clothes"-who is bristling with weapons yet is more impressive than threatening. The soldier/year strides forth, "carrying a rifle on [his] shoulder, /With well-gristled body and sunburnt face and hands, with a knife in the belt at [his] side" (PP, 418). Such is not the case with the personified South in "VirginiaThe West." 12 Virginia is presented as a "noble sire fallen on evil days," who "with hand uplifted, menacing, brandishing, / (Memories of old in abeyance, love and faith in abeyance,) / The insane knife toward the Mother of All" (PP, 429). Unlike the soldier/year, replete with manly virtue and idle weapons, the personified southern state is only vestigially human - insane, threatening, and stripped of memory, love, and faith. It requires the soldier/year to reappear as "plenteous offspring, / Drest in blue, bearing their trusty rifles on their shoulders" and to assert northern control of southern atavism (PP, 429).

One might argue that Whitman constructs these exaggerated portraits of Northern rectitude and Southern insanity to suit the emotional theme of the first phase of his cycle. Drum-Taps frequently is held to have three phases: jingoistic idealism, the shock of experiencing the realities of war, and the tempering of ideals with reality. ${ }^{13}$ Whitman's depictions in "Eighteen Sixty-One" and "Virginia-The West," it would follow, replicate the simplistic mindset of an inexperienced partisan, and this mindset alters, as demonstrated by the speaker in "The Wound-Dresser," who asks, "(was one side so brave? the other was equally brave)" ( $P P$, 443). Nonetheless, while the middle phase of Drum-Taps approaches a more egalitarian view of the South, a comparison of another set of poems from the middle and ending sections of the book, "Vigil Strange I Kept on the Field One Night" and "Reconciliation," shows that, even when sympathetic, Whitman's persona can never absorb the Southern other.

Though Whitman leaves no explicit indications of which side the comrades of "Vigil Strange" fight for, numerous intertextual connections between "Vigil Strange" and "Come Up from the Fields, Father," explicitly set in Ohio, suggest that they are Union soldiers. As Mark Maslan points out in his nuanced discussion of the two poems, "since both poems concern the death of a son, 'Vigil' seems to describe the events that give rise to the letter in 'Come Up from the Fields Father,' 
despite discrepancies between the two narratives (Pete is taken to a hospital when wounded, for example, whereas the comrade in 'Vigil' dies and is buried on the field)." ${ }^{14}$ Maslan also connects the poems through their motifs of wind and envelopes. In "Come Up," there is a "moderate wind" that "cools and sweetens Ohio's villages" (5); in "Vigil Strange," the speaker notes, "cool blew the moderate night-wind" (PP, 436, 438). Furthermore, Maslan links the body of the dead comrade to the letter that foretells the death of the son in "Come Up":

This scene is given more specific reference by the peculiar description of the wrapping of the soldier's body prior to burial: "My comrade I wrapt in his blanket, envelop'd well his form." "Envelop'd" here recalls, but also reverses, the mother's imperative in "Come Up from the Fields Father": "Open the envelope quickly." And this connection is reinforced when the speaker's initial account of how he "folded the blanket well" modulates a few lines later into "I rose from the chill ground and folded my soldier well in his blanket" [emphasis added], as though the logic of the poem demanded that it be not the blanket but the body of the soldier that is folded, like a letter to be placed in an envelope. ("Body as Text," 943-944)

For these reasons, one could reasonably consider "Vigil" to describe a relationship between Northerners.

Whitman grants to this relationship a deep correspondence that allows the dead comrade to live on, absorbed within his friend. Though the relationship between the two does not stress the dynamic of superiority and inferiority accompanying Whitman's absorption of Native Americans, the absorption has a similar function-to erase a painful past event that might impede a better future. Before the comrade's death, the two share a connection through sight and touch: "One look I but gave which your dear eyes return'd with a look I shall never forget, / One touch of your hand to mine O boy, reach'd up as you lay on the ground" ( $P P, 438)$. When the speaker turns to find his comrade dead, he continues their reciprocal relationship, mimicking the corpse's posture by "partially reclining . . . by your side leaning my chin in my hands" (PP, 438). Death here does not mark an ending of their relationship, as features of the poem work to obscure the soldier's death. As Jeff Sychterz argues:

[the dead solider's] face carries no hint of death and his body has no visible wound. Thus the poem hides the corpse from us, and we feel almost no sense of his death as a reality. The apostrophe in "Vigil" also belies the soldier's death in that it keeps him alive, at least in the space of the poem, as a recipient of the speaker's communicated love. ${ }^{15}$

In addition, the comrade now lives though his absorption into the narrator's memories and the feelings; the look the comrade gives him before death, "I shall never forget." According to the speaker, that love, and 
therefore the comrade, will continue after death. The speaker proclaims, "I faithfully loved you and cared for you living, I think we shall surely meet again" (PP, 439).

As the preceding poems in Drum-Taps have been Northern-identified and there are no indications to the contrary within this poem, the reader reasonably will assume that the relationship described in "Reconciliation" is between a Union speaker and his enemy, the corpse of a Confederate soldier. In contrast to "Vigil Strange," the relationship has no correspondence and there is no merging of the two parties, despite the title. Though the speaker refers to the corpse as "a man divine as myself," it is not a statement of correspondence, for it only acknowledges equal relationships to a third factor, the divinity, rather than a shared connection between the two men. Since the enemy is already dead and there are no hints of pre-mortem interaction between them, there can be no exchange of looks and touches as in "Vigil Strange"; there is only a unilateral kiss: "I draw near, / bend down and touch lightly with my lips the white face in the coffin" $(P P, 453)$. Mark Maslan has explored the significance of kisses and corpses in Drum-Taps, and while his argument about their meaning in "A March in the Ranks Hard Prest, and the Road Unknown" and "The Wound-Dresser" is persuasive, it does not extend to "Reconciliation." Maslan observes that Whitman plays with the idea of respiration translating into inspiration. Noting that Whitman was reading Virgil's Aeneid while composing Drum-Taps, Maslan compares the scene in the former where Anna rushes to inhale the spirit of the dying Dido to the interaction between the speaker of "A March" and the dying lad: "just as he seems to absorb the blood he staunches, so he appears to internalize the spirit whose departure from the lad the blood signals. This transfer of spirit from the dying lad to Whitman is suggested as well by the 'half-smile' the lad 'gives' the poet." 16 In "The Wound-Dresser," the transfer is effected through the exchange of kisses: "And if the soldiers' kisses, here as elsewhere, provide Whitman with inspiration, they also authorize him to speak for the soldiers. Hence the importance of the word 'dwells' in the final line of the poem: by claiming that the kisses somehow remain on his lips as he speaks, Whitman claims to incarnate the soldiers" (Possessed, 135). While the persona's incarnation of the soldiers necessitates their absence, that absence follows the moment of exchange. In "Reconciliation," death precedes the contact, so there is no blood, look, or kiss given to the speaker to mark the transfer of spirit that initializes his merging with the soldier. The two remain separate, and, in that way, Whitman cannot overcome the otherness of the Southerner. He is not a temporary voice that fades away and allows life to continue untroubled; he is a stiff corpse that leads the speaker to hope that "war and all its deeds of carnage must in time 
be utterly lost," that time will bring about the erasure he was unable to effect himself $(P P, 453)$.

Decades after the Civil War, for Whitman, Southerners remain animal-like in their fecundity, still driven and driving others to thoughtless desire. Second only to his fiction of long Southern residence is Whitman's fiction of having founded a Southern family. The British poet John Addington Symonds had repeatedly questioned Whitman about the Calamus poems over some twenty years of correspondence. In an August 3, 1890, letter to Whitman, he bluntly asks, "In your concept of Comradeship, do you contemplate the possible intrusion of those semi-sexual emotions $\&$ actions which no doubt do occur between men? .. . I should much like to know whether you are prepared to leave them to the inclinations $\mathcal{E}$ the conscience of the individuals concerned?" 17 Whitman's August 19, 1890, response protests too much that Calamus could only be interpreted within the context of Leaves of Grass and that the thought "that the calamus part has even allow'd the possibility of such construction as mention'd [by Symonds] is terrible" (Corr, 5:72). Whitman changed the subject to his current health and then added this improbable claim as if to further counter the idea that he could be capable of homosexual contemplations:

My life, young manhood, mid-age, times South, \&c. have all been jolly, bodily, and probably open to criticism-

Tho' always unmarried I have had six children - two are dead-One living southern grandchild, fine boy, who writes to me occasionally. Circumstances connected with their benefit and fortune have separated me from intimate relations.

I see I have written with haste $\&$ too great effusion— but let it stand. (Corr, 5:73)

Though this story might be dismissed as a spur-of-the-moment fib, the fact that Whitman spread this tale more widely suggests that it is one of his consciously constructed fantasies of the South. According to Hudgins:

In conversations with his friends Horace Traubel, Richard Bucke, and John Burroughs, Whitman intimates that he has an heir-whether son or grandson is not clear-and that he has convinced the "young fellow" not to come and claim kinship because this heir stands to lose "a little fortune" if he does. Whitman is not, himself, worried that his children might claim his estate: they are "of good family." (91)

As attractive as the idea of a Whitman scion yawping over the bayous is, most critics agree that this was a lie designed to mystify Whitman's sexuality and cut off uncomfortable questions about it. Killingsworth, one of the few scholars to consider Whitman's response to Symonds in detail, argues convincingly that "Whitman did not want to be publicly portrayed as a friend and defender of the upper-class English libertine" 
and had reason to believe that Symonds would publicize his response, hence the denial of Symonds's interpretation of Calamus and its implications about Whitman's proclivities. ${ }^{18}$ These motives, as well as Whitman's own ambivalence towards his sexuality, were no doubt in operation. However, his choice of the South as the venue for the founding of his fictional dynasty provides insight into Whitman's associations with Southerners and again reiterates Whitman's need to control them rhetorically.

As with his earlier correlations of Southerners to animals, Whitman again associates the South with irrational passion and emotional impulse when he mentions "times South" as the only geographical designation connected to his actions which have been "jolly, bodily, and probably open to criticism." Furthermore, he constructs the South as a region of excess, spurred on by the bodily Southerners. As he claims "six children-[and] One living southern grandchild," again emphasizing the South, the implication is that all of these children were produced in the South, one that is further supported by Whitman's comment to Traubel that they are "of good family," suggesting that they all belong to the same family; by this implication, the southern mother apparently produces children in veritable litters or is heedless enough of social conventions to continue to have children out of wedlock. Even his ending, where he apologizes for having "written with haste \& too great effusion" continues the association of Southerners with loss of self-control; just the memory of the excesses to which the South has driven him causes Whitman again to create with "too great effusion." 19

As an antidote to the seductive influences of Southerners, Whitman attempts to assert his control over this Southern impulsiveness. $\mathrm{He}$ figures the Southern grandson as his heir and himself as the head of a Southern dynasty. McClintock observes that the family trope is a powerful tool in colonial discourse "because the subordination of woman to man and child to adult were deemed natural facts, other forms of social hierarchy could be depicted in familial terms to guarantee social difference as a category of nature" (45). Though he cannot claim to be legally in control of his family, since their fabrication is predicated on the fact that he is unacknowledged, he suggests that he does exercise the privilege of a patriarch to advise his heir "not to come and claim kinship" because it would be to his economic detriment. He responds to his (fictional) bout of Southern excess by trying to assert rational control over the impulsive desires of his (fictional) grandson to acknowledge him.

The reasons why Whitman compulsively tried and failed to subsume the South will never be fully accessible to his readers. However, an outlier representation- "As I Lay with My Head in Your Lap Camerado" from Drum-Taps - contributes a possibility worth consideration. While the rest of Drum-Taps and Whitman's representations of Southerners in general portray them as impenetrable others, "As I Lay" shows a suc- 
cessful merging of the poem's persona and a Southerner. "As I Lay" is most frequently interpreted as presenting homosexual bonding as an antidote to the anti-democratic impulses bolstered by the war. Though leery of federal power, "Whitman found himself on the side of national, as opposed to state, sovereignty" in the conflict between the North and the South (Erkkila, 196). In the aftermath of the South's defeat, Whitman feared the "potentially oppressive structures of a peacetime-and heterosexual - economy" would "suppress the role of rebellion, defiance, and conflict" so necessary to keep institutions from ossifying. ${ }^{20}$ In response, the poem asserts "the need for men bonded in love and affection to continue fighting against the anti-individual and anti-democratic forces in American society even after the war has ended" (Kinney, 10). However, what goes unmentioned in these interpretations is the kind of soldier persona Whitman adopts for this poem. In "As I Lay,"Whitman finally incarnates a Southern voice.

When the narrative persona expresses his desire to continue the struggle, the context suggests the struggle for adhesiveness, but the phrasings mimic those of a Confederate soldier. He tells his comrade:

I know I am restless and make others so,

I know my words are weapons full of danger, full of death,

For I confront peace, security, and all the settled laws, to unsettle them,

I am more resolute because all have denied me than I could ever have been had all accepted me.... (PP, 454)

Here, the persona adopts the language of a committed secessionist unwilling to quell the words that will throw the country into war, unwilling to relinquish his cause even if it confronts the settled law of union and turns the rest of the country against him. As he continues, he expresses to his comrade the suspicion that this is a battle they may not win; in effect, his cause may be a lost cause: "Dear camerado! I confess I have urged you onward with me, and still urge you, without the least idea what is our destination, / Or whether we shall be victorious, or utterly quell'd and defeated" (PP, 454). The difference between this poem and "O Magnet-South" is clear. In the earlier poem, the persona speaks about a monolithic and impersonal South; in "Camerado," the persona speaks through a specific aspect of the South. He uses a particular Southern vocabulary to embody deeply personal concerns. Furthermore, the poem resists the urge to control the irrational impulses of the Southerner. The speaker admits the fundamental irrationality of pursuing a course of action that will cause certain disapprobation and unlikely success, yet the poem "still urges" the camerado, and the audience, to continue.

As the Symonds letter and “As I Lay" suggest, Whitman's Southern representations may have been figures of his conflicted feelings about his 
desires. Whitman could not be accused of being demure. Nonetheless, his expressions of sexuality are often so all-encompassing as to be meaningless as markers of specific, personal feelings; all men and women are his lovers, obscuring the focus on any particular man or woman. When questions about personal sexual beliefs arise, such as with Symonds's interrogation, Whitman used the South as a point of projection and, with Symonds, as a beard. The fact that Whitman frequently evokes this projection and just as frequently fails to fully control it is instructive in mapping his reactions to his socially-dangerous desires.

The Southern renaissance's origin story starts with an affront: H.L. Mencken ridiculed the South, designating it the "Sahara of the Bozart"; the Agrarians took their stand; and a literary movement was born. However, as many scholars have shown, the tensions between the South and the rest of the nation were of much older vintage than those brought on by the Scopes trial. In one foundational study of the figure of the South in early national literature, Jennifer Greeson explores how the former colony and new nation of America displaced "European discourses of American colonization ... [which] long had equated the warmth and agricultural productivity of American possessions with corruption, despotism, violence, slavery, luxury, racial heterogeneity, 'passion or desire'-all manner of vice and degeneracy ostensibly unknown in the civilized mother nations" from America as a whole to the southern region of America, then adopted that depiction to align themselves with more established nations. ${ }^{21}$ In America's shift from colony to nation, Greeson asserts:

Cultural understandings of the south remained unchanged; what changed was the national metropole that the south enriched, from London to Boston / New York / Philadelphia. In the pages of early national travelogues, the freedom and independence of the new United States was predicated upon both opposition to and ownership of its colonial south. (230)

Even the American bard, the poet who weaves the many into one, was not immune to those tensions. Whitman's views on the South provide us with another link in the chain that connects the corrupt southern city in Crevecouer's Letter from an American Farmer to Mencken's land of the "homo neanderthalensis," as well as give us insight into the South's meaning in Whitman's internal landscape.

North Georgia College E State University 


\section{NOTES}

1 Deborah S. Kolb, "Walt Whitman and the South," Walt Whitman Review 22 (1976), 3; Andrew Hudgins, "Walt Whitman and the South," Southern Literary Fournal 15 (Fall 1982), 91-100.

2 Horace Traubel, With Walt Whitman in Camden (various publishers, 1906-1996), 2:445. Hereafter, $W W W C$.

3 See Kolb, 9; Hudgins, 97; and Betsy Erkkila, Whitman the Political Poet (Oxford: Oxford University Press, 1989), 51.

4 Edward Said, Orientalism (New York: Pantheon, 1978), 35.

5 Walter Grünzweig, "Noble Ethics and Loving Aggressiveness: The Imperial Walt Whitman" in Serge Ricard, ed., An American Empire: Expansionist Cultures and Policies 1881-1917 (Aix-en-Provence: University of Provence, 1990), 153, 162; David Simpson, "Destiny Made Manifest:The Styles of Whitman's Poetry" in Homi Bhabba, ed., Nation and Narration (New York: Routledge, 1990), 192; George Handley, New World Poetics: Nature and the Adamic Imagination of Whitman, Neruda, and Walcott (Athens: University of Georgia Press, 2007), 114; M. Jimmie Killingsworth, Whitman and the Earth: A Study in Ecopoetics (Iowa City: University of Iowa Press, 2004), 85. Hereafter, Earth.

6 Edward Said, Culture and Imperialism (New York: Knopf, 1993), xii-xiii. Hereafter, Culture.

7 Walt Whitman: Poetry and Prose, ed. Justin Kaplan (New York: Library of America, 1996), 351. Hereafter, PP.

8 Kolb, 5; Michael Dressman, "Goodrich's Geography and Whitman's Place Names," Walt Whitman Review 26 (1980), 64-67.

9 Anne McClintock, Imperial Leather: Race, Gender, and Sexuality in the Colonial Conquest (New York: Routledge, 1995), 43.

10 Jerome Loving, “'A Southerner as soon as a Northerner': Writing Walt Whitman's Biography," in Susan Belasco, Ed Folsom, and Kenneth M. Price, eds., Leaves of Grass: The Sesquicentennial Essays (Lincoln: University of Nebraska Press, 2007), 363.

11 Walt Whitman, Leaves of Grass (Boston: Thayer \& Eldridge, 1860), 20. Hereafter, LG 1860. Available on the Walt Whitman Archive (www.whitmanarchive.org).

12 "Virginia-The West" was first published in Kansas Magazine in 1872 and added to the Drum-Taps section for the 1881 edition of Leaves of Grass.

13 For further discussion of the structure of Drum-Taps, see Denise Askin, "Retrievements Out of the Night: Prophetic and PrivateVoices in Whitman's Drum-Taps," American Transcendental Quarterly 51 (1981), 211-223; William Burrison, "Whitman's Drum-Taps Reviewed:The Good Gray, Tender Mother-Man and the Fierce, Red, Convulsive Rhythm ofWar," in Joann P. Krieg, ed., Walt Whitman: Here and Now (Westport, CT: Greenwood, 1985), 157-169; and Anthony Szczesiul, "The Maturing Vision of Walt Whitman's 1871 Version of Drum-Taps," Walt Whitman Quarterly Review 10 (Winter 1993), 127-141.

14 Mark Maslan, "Whitman's 'Strange Hand': Body as Text in Drum-Taps," ELH 58 (Winter 1991), 943. Hereafter, "Body as Text." 
15 Jeff Sychterz, “'Silently Watch(ing) the Dead': The Modern Disillusioned War Poet and the Crisis of Representation in Whitman's Drum-Taps," Discourse: Fournal for Theoretical Studies in Media and Culture 25 (Fall 2003), 17-18.

16 Mark Maslan, Whitman Possessed: Poetry, Sexuality, and Popular Authority (Baltimore, MD: Johns Hopkins University Press, 2001), 122-123. Hereafter, Possessed.

17 Walt Whitman, The Correspondence, ed. Edwin Haviland Miller (New York: New York University Press, 1969), 5:72 n18. Hereafter, Corr.

18 M. Jimmie Killingsworth, "Whitman and the Gay American Ethos," in David S. Reynolds, ed., A Historical Guide to Walt Whitman (New York: Oxford University Press, 2000), 73-74.

19 This too is a charade. Miller observes that "he took the trouble to compose a draft letter-with an artfully deceptive sentence at the conclusion" and therefore "this was no off-hand answer" as he claimed (Corr, 5:73n18).

20 Erikkila, 221; Katherine Kinney, "Whitman's 'Word of the Modern' and the First Modern War," Walt Whitman Quarterly Review 7 (Summer 1989), 2.

21 Jennifer Rae Greeson, "The Figure of the South and the Nationalizing Imperatives of Early United States Literature," Yale Fournal of Criticism: Interpretation in the Humanities 12 (Fall 1999), 216. 